\title{
A STUDY OF THE CAPSID BUGS FOUND ON APPLE TREES.
}

\author{
By F. R. PETHERBRIDGE AND M. A. HUSAIN 1 .
}

School of Agriculture, Cambridge.

(With Plates IX-XI.)

CONTENTS.

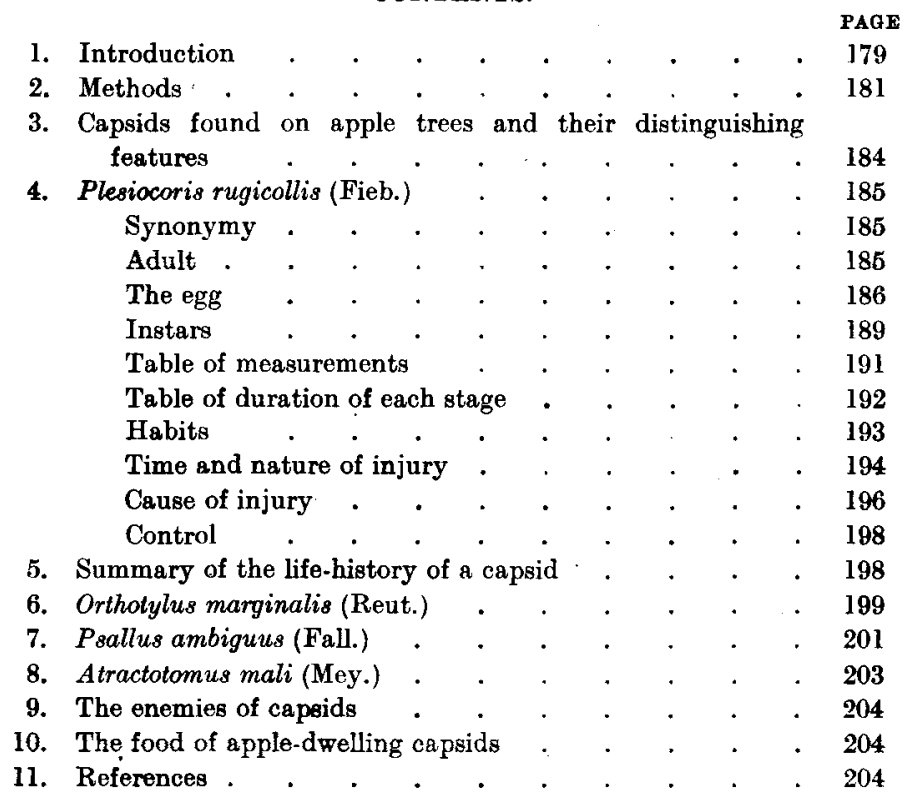

\section{INTRODUCTION}

The damage done to apples by bugs of the family Capsidae has now become a very serious trouble to fruit growers in this country and a detailed knowledge of those found on apple trees is therefore of immediate importance. This work was undertaken at the suggestion of Fryer who has, during the past few years, made observations on these insects $(11,12,12 a)$.

1 Mr Husain wishes to thank the Government Grant Committee of the Royal Society for the grant given to him to carry out this work. 


\section{A Study of the Capsid Bugs found on Apple Trees}

The problem has been studied mainly from an economic standpoint, our main object being to find out the amount of damage caused by each species, to study their life-histories and the nature and cause of the injuries done to the leaves, shoot and fruit by the various stages.

Problems of great biological interest and possibly of economic importance have arisen during the course of this work which we have been unable to investigate owing to pressure of time. One season is a very short time to study all the aspects of such a problem as this, and we hope if circumstances permit to continue this work next season. Our justification for the publication of this rather incomplete paper is in the hope that the observations contained in it may be of immediate use in helping to control this serious pest, and also that under such abnormal conditions as exist at the present time, the authors may be unable to continue this work, in which case the observations made may be of some help to future investigators.

A large number of the Capsidae live on the juices of plants which they suck by means of their long rostra, and it is probably as a consequence of this that so many of them have been recorded, some rightly and others wrongly, as plant pests. In America the following have been recorded as damaging fruit trees:

\section{Heterocordylus malinus Reut. \\ Lygidea mendax Reut. \\ Lygus pratensis Fab. \\ Neurocolpus nubilus Say. \\ Paracalocoris colon Say.}

Fryer points out that of these only Lygus pratensis is present in this country.

In England the following among others have been recorded as damaging apple trees:

\section{Atractotomus mali Mey. \\ Lygus pratensis Fab. \\ Orthotylus marginalis Reut. \\ Plesiocoris rugicollis Fall. \\ Psallus ambiguus Fall.}

Lygus pratensis is recorded as producing dimples on apples, whereas the others are recorded as damaging the leaves, shoots and fruit.

As Fryer has pointed out (11) there is a great deal of confusion as regards the real pest and the status of the various capsids found so commonly in affected orchards. Unfortunately the presence of a species 
on damaged trees seems to have been regarded as sufficient evidence to record it as the cause of the trouble.

Theobald(24-28) repeatedly mentions Atractotomus mali, Orthotylus marginalis and Psallus ambiguus as the culprits. Schöyen (21) mentions Orthotylus marginalis, Plesiocoris rugicollis and Psallus ambiguus as doing damage in Sweden. We do not know on what evidence these statements are based as no details are given, but we have found that it is possible to visit an orchard in which the apples have been badly marked by Plesiocoris rugicollis after this species has disappeared and when one or more of the other three species are still present. We think therefore that very probably the damage has been attributed to the wrong species. It is of course possible that in Sweden the injury might be done by a species which is harmless in this country, but in the absence of direct evidence this should be regarded as doubtful.

Fryer has pointed out that Plesiocoris rugicollis is the more serious pest and has shown by direct experiment that it causes the typical damage to the leaves, and that Psallus ambiguus does not(12). Fryer and Petherbridge also showed by direct experiment that Plesiocoris rugicollis damages the fruit and shoot and that Psallus ambiguus and Atractotomus mali do not(12a).

Our experiments and observations show that Plesiocoris rugicollis causes marked damage to the leaves, shoots and fruit and is responsible for most of, if not all, the damage in the Wisbech district, and that Atractotomus mali, Orthotylus marginalis and Psallus ambiguus although they feed on the juices of the apple do not cause any apparent damage to the varieties badly marked by Plesiocoris rugicollis. In no case have we found either of these three species causing any visible damage to apples.

The life-histories of a number of forms have been worked out in America $(6,7,16,18,29)$ but very little work has been done in that direction in this country.

\section{METHODS.}

Observations were made during the season of 1917 chiefly in badly attacked orchards at West Walton near Wisbech where the bugs used for experimental work were also obtained. Observations were also made in unattacked orchards near Cambridge.

April 14th is the earliest record of the hatching of $P$. rugicollis (12) so we started our visits to Wisbech at the beginning of April but obtained no young capsids during the whole of this month. Twigs of apple were brought back and searched for eggs. We could not find the 


\section{A Study of the Capsid-Bugs found on Apple Trees}

eggs by means of a surface examination even after cleaning the twigs with dilute potash, but were able to find them by peeling the bark when the eggs remained sticking to it. We kept a number of these twigs in water in the laboratory in the hope that young larvae would hatch out from some of the eggs. Fortunately we were rewarded by getting a number of young $P$. rugicollis larvae (one of which we observed emerging from an egg) from shoots brought in at the end of April.

These started to hatch on May 5th. Up to this date no capsid larvae had hatched at Wisbech, but a visit on May 7 th revealed the presence of many newly hatched larvae. The young leaves of the shoots on which they were found were marked with brown spots.

As we were unable to identify the young capsids until later on we classified them under the headings $A, B, C$, etc. The larvae and nymphs were taken to the laboratory, carefully examined, classified and some of them measured and drawn. Some were preserved, others placed singly on shoots in cages, and others put into sleeves on apple trees, each sleeve containing a single bug. Young bugs were brought in three or four times a week and the development in the laboratory checked by the stages found at Wisbech. All the different stages found were placed on shoots in cages and sleeves and their behaviour noted. We were thus able to find out which of the species did damage and at what stages the damage was done to the leaves, fruit and young stems. Precedence was given to $P$. rugicollis in our observations as this was soon found to be the only culprit. Altogether we had over fifty cages of $P$. rugicollis and about an equal number of the other bugs. We sleeved about fifty $P$. rugicollis, and a large number of the other bugs each in a separate sleeve. We sleeved some $P$. rugicollis singly on black currants and plums, and also took some larvae and nymphs of $\boldsymbol{P}$. rugicollis which were damaging black currants at Histon and sleeved them at different stages on apples.

The sleeves gave very good results and there were very few casualties. We were successful in rearing them in cages, but there were more deaths on account of their drowning or falling down at night. At first we put the twigs in beakers of water with a bug on each twig, but they often crawled down the twigs and got drowned. We then kept the twigs in small flasks of water, plugging the mouth of the flask with cotton wool and placed it in a large beaker covered at the top with a piece of muslin. These cages proved fairly successful, the chief drawback being that the bugs often fell down into the beaker and had to be replaced two or three times a day. The shoots were changed every two or three days in order to keep conditions as normal as possible. In spite of the 
difficulties encountered we were able to carry through to the adult stage three individuals of $P$. rugicollis which hatched in the laboratory. From the cage cases we got a complete record of the times of moulting and the duration of each instar which on comparison proved very similar to those under normal conditions at Wisbech. All doubtful cases were discarded and the figures given in Table II (p. 192) are those about which there is no doubt.

The records of the life-history in the cages in the laboratory were compared with the sleeve cases at the farm and with those under normal conditions at Wisbech and were found to agree closely, in the laboratory the hatching and certain moults were in some cases a day or so ahead. We failed to find $P$. rugicollis copulating in spite of the fact that we put males and females together on shoots in the cages. We tried to watch the process of egg laying, but in spite of careful watching we were unsuccessful. For this purpose we had lengths of glass tubing about one inch in diameter, closed at one end by a piece of muslin and at the other by a cork with a hole in it. An apple twig with a $+P$. rugicollis on it was introduced in the tube and the end put through the hole in the cork; the basal end of the twig being outside was placed in water and so kept fresh. A later examination of these twigs showed that eggs had been laid. Some of these twigs with eggs were dissected and photographed.

During the early part of the experiment shoots of Bramley's Seedling, Early Victoria (Emneth Early), Grenadier, Keswick Codling, Lord Grosvenor and Worcester Pearmain were used in the cages, but later on, owing to the difficulty of getting twigs, we had no time to find out the varieties used.

$P$. rugicollis caused characteristic markings in every case. Details of these markings are given under the description of the injury done by this species.

Psallus ambiguus, Orthotylus marginalis and Atractotomus mali were at first put on shoots of Keswick Codling and Bramley's Seedling and later on several other varieties, but as far as we could see they did not change the appearance of the leaf or fruit and certainly did not cause any markings of a similar nature to those caused by $P$. rugicollis.

The drawings were done by means of a camera lucida.

A large number of measurements of the different parts are given as the length of a larva or nymph is very variable according to its food supply, a well-fed larva being much longer than a starved individual as in the latter the basal joints of the abdomen become telescoped. Owing to this we subdivided $P$. rugicollis into $A$ and $B$ and expected to get two 


\section{A Study of the Capsid Bugs found on Apple Trees}

different species. The measurements of the antennae and legs are not so variable.

An account of the life-histories of the various species is given below.

\section{CAPSIDS FOUNI) ON APPLE TREES.}

In this country apple trees harbour a fairly large number of the different genera of the Capsidae. From orchards near Wisbech and Cambridge we collected seven different genera and two species of one genus whilst other observers have recorded other species, e.g. Lygus pratensis.

The following is a list of the species found:

\begin{tabular}{|c|c|c|c|}
\hline \multirow{3}{*}{ Plesiocoris rugicollis } & \multirow{3}{*}{$\begin{array}{l}\text { District } \\
\left\{\begin{array}{l}\text { Wisbech } \\
\text { Cambridge }\end{array}\right.\end{array}$} & \multirow{2}{*}{$\begin{array}{c}\text { Numbers } \\
\text { very abundant }\end{array}$} & Relnarks \\
\hline & & & $\begin{array}{l}\text { affected orchards on apples and } \\
\text { currants }\end{array}$ \\
\hline & & ," & $\begin{array}{l}\text { not found on apples but abundant } \\
\text { on currants }\end{array}$ \\
\hline Orthotylus marginalis & $\begin{array}{l}\text { Wisbech } \\
\text { Cambridge }\end{array}$ & " & $\begin{array}{l}\text { affected orchards } \\
\text { unaffected orchards }\end{array}$ \\
\hline Psallus ambiguus & $\begin{array}{l}\text { Wisbech } \\
\text { l Cembridge }\end{array}$ & abundant" & $\begin{array}{l}\text { affected orchards } \\
\text { unaffected orchards }\end{array}$ \\
\hline Atractotomus mali & $\left\{\begin{array}{l}\text { Wisbech } \\
\text { ( Cambridge }\end{array}\right.$ & $\begin{array}{l}\text { few } \\
\text { fair number }\end{array}$ & $\begin{array}{l}\text { affected orchards } \\
\text { unaffected orchards }\end{array}$ \\
\hline Phylocoris ulmi and & ( Wisbech & few & affected orchards \\
\hline Phytocoris populi & Cambridge & " & unaffected orchards \\
\hline Pilophorus perplexa & $\left\{\begin{array}{l}\text { Wisbech } \\
\text { Cambridge }\end{array}\right.$ & ", & $\begin{array}{l}\text { affected orchards } \\
\text { unaffected orchards }\end{array}$ \\
\hline Aetorhinus angulatus & $\left\{\begin{array}{l}\text { Wisbech } \\
\text { Cambridge }\end{array}\right.$ & $\begin{array}{c}\text { abundant } \\
\text {," }\end{array}$ & $\begin{array}{l}\text { affected orchards } \\
\text { unaffected orchards }\end{array}$ \\
\hline
\end{tabular}

As pointed out above, of these eight species, Plesiocoris rugicollis is the only one which we have found marking the leaves, shoot or fruit and therefore we shall deal with this species in greater detail. The adults of all these genera can be easily identified (Saunders, Heteroptera) but it is not always possible to recognise the genus in the earlier stages.

The following characters may be useful in identifying the young stages of the above species:

Plesiocoris rugicollis hatch in April or early in May.

Yellowish green becoming greener at each successive moult.

Terminal joint of antenna pinkish brown.

Lips of dorsal abdominal gland well marked.

Mark the leaves with brown spots. 
Orthotylus marginalis hatch about a fortnight later than $P$. rugicollis.

Slightly smaller, orange yellow in first stage, later greenish yellow with bluish tinge, especially marked on lower surface.

Large orange coloured dorsal abdominal gland with faint lips.

Terminal joint of antenna smoky orange. More hairy than P. rugicollis.

Psallus ambiguus hatch about the same time as $P$. rugicollis.

Smaller, orange yellow. Terminal joint of antenna smoky orange, and very hairy.

Atractotomus mali (Pl.X, fig.11) hatch about a month later than P.rugicollis.

Small, red, two basal joints of the antenna very much thickened.

Phytocoris populi hatch nearly a month later than $P$. rugicollis.

Large. Antennae and posterior legs long. Mottled, ground colour white with yellow and brown spots; thorax with dark broad lateral bands. Antennae and legs banded and covered with long hairs.

Phytocoris ulmi differs from the preceding in being very much darker. The spots are green, brown and black.

Pilophorus perplexa. Dark reddish brown and bear a marked resemblance to ants with which they are usually found in association. Head large flattened posteriorly and overlaps the front margin of pronotum. A narrow white band across the anal margin of pronotum and a wider white band across the anal half of tergite I. Terminal joint of antenna white.

Aetorhinus angulatus hatches nearly a month later than $P$. rugicollis.

Small, slender, yellowish green, recognisable by its very long antennae and black bases of the tibere.

\section{PLESIOCORIS RUGICOLLIS (FIEBER)}

\section{SYNONYMY.}

Lygus rugicollis Falléri. Mono. Cimi. p. 76, 1818.

Phytocoris rugicollis Falléri. Hem. Svec. 1. 79. 6.

Capsus rugicollis Schâff. Wanz iii. 80-98, Fig. 299.

Phytocorrs marginalis Zelt. I. L. 271, 5.

Plesiocoris rugicollis Fieb. Eur. Hem. 272.

Reuter Cap. 2. 43.

Lygus rugicollis Doug. and Scott. E. M. M. Iv. 50.

Adult (Pl. X, fig. 10).

The genus Plesiocoris Fieb. consists of only one species. The adult Plesiocoris rugicollis is elongate oval; bright green; head, front part of 


\section{A Study of the Capsid Bugs found on Apple Trees}

pronotum, sides of elytra and legs yellow. Sparsely pilose. Elytra subparallel in $\delta$ and comparatively more rounded in $q$.

Head small, with large, dark red, compound eyes, nearly touching the pronotum and projecting slightly beyond its lateral margins. Vertex carinated posteriorly.

Pronotum with a very distinct narrow yellow collar and two very prominent callosities just behind it. Strongly rugose. Posterior margin not emarginate and covers the mesonotum. Sides straight.

Elytra green with yellow margin; sparsely covered with short thick almost black hairs. Membrane hyaline, two cells with green nervures and with a clouded area round the inner angle of the large cell.

Antennae medium length; covered with short thick black hairs and longer and finer light hairs; basal joint green and thicker than the other joints. Second joint longest; lower portion green, upper half dark. Terminal joint three-quarters the length of the third joint, both together shorter than the second; both dark. When cleaned and mounted in balsam terminal and sub-terminal joints pinkish brown.

Legs yellowish green, with short brownish hairs. Tibia with fine brownish spines. Tip of tibia dark and thickly covered with hairs which become thicker and longer as they approach the tip. Tarsi 3-jointed, covered with fine hairs; two basal joints sub-equal, terminal longest; tips dark with curved claws and a pair of transparent arolia.

\section{The EGG.}

\section{Time of egg-laying.}

The females of $P$. rugicollis brought from Wisbech from about the third week of June to the beginning of July were enclosed in glass tubes with apple twigs, and were observed to have laid eggs in these shoots. In spite of a careful watch, the actual process of egg-laying escaped observation. It may be that the eggs are laid during the early hours of the morning. There is no doubt that they are laid after long intervals, as in a number of cases there were only two or three eggs after a female had been on the twig for over a week. During the egg-laying period the bug keeps feeding on tender leaves and soft terminal parts of the stems which show the characteristic purple-brown spots. It would be interesting to find out the number of days that a female takes to develop eggs after fertilisation and the time taken to lay all the eggs. We are inclined to think that egg-laying continues all through the later part of the life of an adult female. 


\section{Position of eggs.}

The eggs laid in the laboratory were carefully compared with those dissected out of the twigs brought from Walton, and their identity confirmed by comparison with the eggs dissected out of a female. In all cases the eggs were laid in the present year's soft stem, in many cases very near the apex and in some cases at the thickened bases of the twigs. They were laid indiscriminately in lenticels or in slits made for the purpose in other parts of the stem, preference, however, was given to a wound that had become soft, as shown by the presence of a number of eggs in such situations (PI. IX, fig. 3). They were usually laid singly, but in some cases more than one egg was found at the same level both in lenticels and wounds. In the latter situation the number may increase to five or six.

After a little practice the position of an egg can be easily detected either as a small brown spot or a little slit in the stem, and under magnifcation one can easily see the brownish cap of the egg with its whitish rim (see Pl.IX, fig. 2). Only a small portion of the cap if any is above the surface of the stem. The long hairs of the stem, to a large extent, conceal the position of the egg which is often made more obscure by the hairs sticking together on account of the exudation of sap from the wound made in the stem, and by the liquid from the body of the female. After a few months the growth of green algae and particles of dust make it impossible to detect an egg by an external examination of a shoot. But if the bark is peeled off carefully the eggs may be detected on the inner side as they usually come off with it. There are no processes extending out from the egg cap.

\section{Direction of the egg in the stem.}

The eggs are laid with their long axes more or less radial to the stem and often penetrate the xylem and in young stems reach the pith. Sometimes they are more tangential and lje wholly in the bark, this is particularly the case when a number of eggs are laid at the same level with their caps close to each other on the surface. They lie somewhat obliquely with their concave side facing the apices of the twigs and the blunt end situated in front of the cap (see Pl. IX, fig. 1). Only in one case was an egg found with its convex side towards the apex of the twig (Fig. 3). The greatest diameter of the egg cap is in line with the long axis of the shoot and only in one case when the egg was laid in the scars of the previous year's bud scales was the long axis of the egg cap at right angles to the long axis of the stem. This can be explained on simple mechanical 


\section{A Study of the Capsid Bugs found on Apple Trees}

grounds. The female must have a strong hold on the stem for the action of its ovipositors and for this it seems necessary that she should hold on in the direction of the stem and not crosswise. Moreover it is easier to separate the fibres of the xylem than to cut across them and a longitudinal slit does not interfere with the growth of the surrounding parts and the egg remains in a fresh condition. The tissue around the egg remains in a healthy condition, except probably around the collar of the egg.

From the position of the egg it would appear that the female faces the base of the twig when ovipositing, and this is borne out by the structure of the ovipositor which is concave on the dorsal side [i.e. posterior side when ovipositing] and by actual observation on the position of an egg which was carried about by a female (its laying in tissue somehow or other interfered with) with its convex side directed ventrally. The direction of the egg shows that the ovipositor acts almost vertically to the stem only a little upward in direction. We cannot suggest any reason for the female facing towards the base of the shoot for oviposition.

\section{Structure of the egg.}

The egg has been described by Fryer(12) as somewhat resembling the rubber portion of a fountain pen filler. It is markedly curved along its length, with one end bluntly rounded and thick, and gradually narrowing towards the opposite end forming a neck-like region and slightly expanding into a cap at the top end (see Pl. IX, fig. $4 A$ ). The egg is cream coloured, the surface is smooth and glistening and the shell is strong and elastic. The body of the egg is slightly flattened by the fibres of the plant pressing against it. This part of the egg is thus oval in cross-section becoming almost circular in the region of the neck. The cap is dark brown in colour and strongly chitinized. It shows strongly marked longitudinal striations all round, which are probably hairs that hold the cap to the egg-shell and at the base of it are seen a few scale-like markings. The function of these markings is obscure. The opening of the egg is closed by a strong oval disc, brown in colour and showing curious processes on both surfaces. The outer rim of the cap is whitish with radially arranged lamellar-like structure when seen from above.

As mentioned above, the egg dissected out of a twig is flatter than one dissected out of a female. It measures $1.4 \mathrm{~mm}$. in length, $0.3 \mathrm{~mm}$. at its greatest width, and $0.25 \mathrm{~mm}$. in the region of the neck.

In the body of a mature female the eggs lie in longitudinal direction, all with their caps pointing forwards. The whole body is practically full of eggs, which reach right up to the prothorax. The largest number 
dissected out of one female was fourteen, but it is probable that the actual number is more than this.

The eggs live in the shoots all through the winter and the young larvae hatch from them the following April or May.

\section{Description OF THE INSTARS.}

Instar I (Pl.IX, fig. 5). Length 1.1-1.4 mm., small, slender, fragile, semitransparent. When just hatched pale yellow, turning greenish and darker in a few hours. On the head and thorax are smoky patches interrupted on the thorax by a mid-dorsal pale line which bifurcates on the head at the level of the eyes. The smoky colour is in the chitin whilst the actual colo ir of the bug is due to pigments in the tissues of the body.

Head relatively large, marked longitudinal groove just in front of vertex; yellow, with smoky shades interrupted by a Y-shaped pale line. A row of short thick black hairs is present on the vertex and a few longer hairs on the front of the head. Eyes, compound, large, deep carmine in colour, nearly touching the pronotum.

Thorax increases in width up to the metathorax.

Pronotum almost rectangular, anterior margin slightly curved, angles rounded. Light green with smoky patches interrupted by mid-dorsal pale line. Row of hairs on posterior margin and a few irregularly scattered hairs.

Mesothorax with smoky patches; broader than prothorax.

Metathorax shortest and broadest, smoky patches narrower.

Abdomen pyriform, slightly longer than broad; greatest breadth across segments II-IV. (In a well-fed individual the abdomen is distended and almost circular in cross-section; but in a starved specimen it becomes flatter and the first two abdominal segments become telescoped.) Yellowish green, with a pale line extending from segments III-X, smoky patch on segment I. A large circular yellow area is present in the mid-dorsal region of segment III. This is the pocketshaped dorsal abdominal gland seen through the cuticle; its orifice is between segments III and IV; the anterior lip is the black thickened part of the anal margin of tergite III. The anterior part of tergite IV opposite this is dark and the two lips enclose a light coloured area. A row of thick short black hairs on each tergite, longer on segments VIII-X; segment IX also has a number of small hairs. Whole abdomen covered with a fine fur of setae.

Appendages.

Antennae medium-sized, slender, at first pale yellowish green, 


\section{A Study of the Capsid Bugs found on Apple Trees}

later dusky. Terminal joint yellow at base, changing into orange, pinkish brown, orange and yellow towards the tip. This pinkish brown colour is characteristic of all the instars of this species. Terminal joint longest; $1 \frac{1}{2}$ times that of the third joint and slightly thicker. It is thickly covered with hairs, other joints fewer hairs.

Legs short, thick, at first pale, then turn yellowish green and dusky, tarsi almost black. Femora light green with a few black hairs slightly longer than those on the body. Tibia slender with more and longer hairs. Tarsi 2-jointed, the terminal joint being the longer. Two black curved claws with transparent aroliae.

Proboscis greenish yellow with a black tip; reaches to about the middle coxae.

Instar II (Pl. IX, fig. 6). Length $1 \cdot 5-2 \cdot 2 \mathrm{~mm}$. Resembles Instar I in shape. At first yellowish with transparent appendages but soon becomes darker. The body is distinctly greener than Instar I. The smoky shades present on the head, thorax and abdomen are now absent. The pale middorsal Nine on the abdomen and thorax bifurcating on the head is still present.

Characteristic differences. Nearly double as long. Terminal joint of antenna slightly longer than joint II; joint II distinctly longer than joint III. Posterior margin of mesonotum sfightly emarginate.

Head large, no groove present; yellow with $Y$-shaped pale line present. Eyes deep red, and the number of facets has increased.

Thorax, shape as Instar I.

Pronotum trapeziform, anterior margin slightly narrower than the posterior; two callosities present.

Abdomen pyriform; longer than broad. No smoky shade on segment I. The yellow mid-dorsal abdominal gland is still present on segment III and its lips are well marked.

Appendages.

Antennae medium sized, slender-colour as in Instar I; basal joint thickest; terminal joint longest, slightly longer than joint II.

Legs similar to Instar I but longer.

Probqscis reaches to about the middle coxae, colour as in Instar I.

Instar III (Pl. X, fig. 7). Length 2-1-2.8 mm. Outline and colour as Instar II; mid-dorsal line faint.

Characteristic structural peculiarities. The second joint of the antenna has increased relatively more than the other joints. Terminal joint of 
antenna now shorter than the second joint which is the longest; the third joint shorter than the fourth. Wing pads, small thickened lobes at the posterior angles of meso- and metanotum, the former being slightly larger. The wing pads become darker when the nymph is about to moult. Other characters similar to Instar II, the yellow spot on the abdominal segment III being rather faint.

Instar IV (Pl. X, fig. 8). Length 1.33-1.99 mm.

Characteristic structural peculiarities. A further increase in the relative

Table I. Plesiocoris ruatcollis (measurement in milumetres).

\begin{tabular}{|c|c|c|c|c|c|c|c|}
\hline & & Instar I & Instar II & Instar III & Instar IV & Instar V & Adult \\
\hline Head & $\begin{array}{l}\text { Length } \\
\text { Width } \\
\text { Distance be } \\
\text { twoen eyes }\end{array}$ & $\begin{array}{l}.21 \\
.4 \\
.26\end{array}$ & $\begin{array}{l}\cdot 34 \\
\cdot 52 \\
\cdot 34\end{array}$ & $\begin{array}{l}\cdot 43 \\
.64 \\
\cdot 39\end{array}$ & $\begin{array}{r}.52 \\
.79 \\
.45\end{array}$ & $\begin{array}{l}.54 \\
.9 \\
.5\end{array}$ & $\begin{array}{l}.56 \\
.99 \\
.5\end{array}$ \\
\hline Prothorax & $\begin{array}{l}\text { Length } \\
\text { Width }\end{array}$ & $\begin{array}{l}.21 \\
.38\end{array}$ & $\begin{array}{l}.26 \\
.55\end{array}$ & $\begin{array}{l}\cdot 31 \\
-69\end{array}$ & $\begin{array}{l}.4 \\
.86\end{array}$ & $\begin{array}{c}\cdot 6 \\
1 \cdot 15\end{array}$ & $\overline{-}$ \\
\hline Mesothorax & $\begin{array}{l}\text { Length } \\
\text { Width }\end{array}$ & $\begin{array}{l}\cdot 14 \\
.48\end{array}$ & $\begin{array}{l}\cdot 19 \\
.6\end{array}$ & $\begin{array}{l}.28 \\
.86\end{array}$ & $\frac{.43}{-}$ & $\stackrel{\cdot 67}{-}$ & - \\
\hline Metathorax & $\begin{array}{l}\text { Length } \\
\text { Width }\end{array}$ & $\begin{array}{l}\cdot 12 \\
.49\end{array}$ & $\begin{array}{l}\cdot 14 \\
.66\end{array}$ & $\begin{array}{r}\cdot 17 \\
.88\end{array}$ & $\stackrel{-17}{-}$ & $\cdot 19$ & - \\
\hline Wings & $\begin{array}{l}\text { Length } \\
\text { Width }\end{array}$ & $=$ & $=$ & $=$ & \begin{tabular}{|c|}
.85 \\
1.4
\end{tabular} & $\begin{array}{l}1.7 \\
1.8\end{array}$ & $\overrightarrow{-}$ \\
\hline \multirow[t]{2}{*}{ Abdomen } & $\begin{array}{l}\text { Length } \\
\text { Width }\end{array}$ & $\underset{-57}{.43-73}$ & $\stackrel{\cdot 8-1.29}{\cdot 69}$ & $\begin{array}{c}1 \cdot 1-1 \cdot 47 \\
.95\end{array} \mid$ & $\begin{array}{c}1.33-1.9 \\
1.3\end{array}$ & $\underset{1.7}{1.9-2.37}$ & - \\
\hline & Total length & $1 \cdot 1-1 \cdot 4$ & $1 \cdot 5-2 \cdot 2$ & $2 \cdot 1-2 \cdot 8$ & $2 \cdot 7-3 \cdot 4$ & $3 \cdot 6-4 \cdot 27$ & $5.9-6.0$ \\
\hline \multirow[t]{2}{*}{ Antennae } & $\begin{array}{l}1 \\
2 \\
3 \\
4 \\
\end{array}$ & $\begin{array}{l}.14 \\
.20 \\
.17 \\
.31\end{array}$ & $\begin{array}{l}.17 \\
.34 \\
.26 \\
.40\end{array}$ & $\begin{array}{l}.22 \\
.54 \\
.40 \\
.45\end{array}$ & $\begin{array}{l}.29 \\
.86 \\
.57 \\
.52\end{array}$ & $\begin{array}{c}.38 \\
1 \cdot 3 \\
.76 \\
.57\end{array}$ & $\begin{array}{r}.55 \\
1.81 \\
.91 \\
.70\end{array}$ \\
\hline & Total length & .82 & $1 \cdot 17$ & $1 \cdot 61$ & $2 \cdot 24$ & 3.01 & $3 \cdot 8$ \\
\hline Leg I & $\begin{array}{l}\text { Femur } \\
\text { Tibia } \\
\text { Tarsus }\end{array}$ & $\begin{array}{l}.25 \\
.34 \\
\cdot 19\end{array}$ & $\begin{array}{l}-41 \\
-46 \\
.24\end{array}$ & $\begin{array}{l}.52 \\
.66 \\
.28\end{array}$ & $\begin{array}{l}\cdot 69 \\
\cdot 83 \\
\cdot 34\end{array}$ & $\begin{array}{c}.78 \\
1 \cdot 1 \\
\cdot 43\end{array}$ & $\begin{array}{l}\mathbf{1} \cdot 29 \\
\mathbf{1} \cdot \mathbf{6} \\
\cdot 58\end{array}$ \\
\hline Leg II & $\begin{array}{l}\text { Femur } \\
\text { Tibia } \\
\text { Tarsus }\end{array}$ & $\begin{array}{l}\cdot 31 \\
.38 \\
\cdot 2\end{array}$ & $\begin{array}{l}\cdot 46 \\
\cdot 55 \\
\cdot 25\end{array}$ & $\begin{array}{l}.6 \\
.78 \\
.28\end{array}$ & $\begin{array}{r}.83 \\
1 \cdot 09 \\
\cdot 39\end{array}$ & $\begin{array}{l}1 \cdot 1 \\
1 \cdot 48 \\
\cdot 5\end{array}$ & $\begin{array}{r}1.48 \\
1.82 \\
.62\end{array}$ \\
\hline Leg III & $\begin{array}{l}\text { Femur } \\
\text { Tibia } \\
\text { Tarsus }\end{array}$ & $\begin{array}{l}\cdot 36 \\
\cdot 45 \\
\cdot 22\end{array}$ & $\begin{array}{l}.47 \\
.69 \\
\cdot 29\end{array}$ & $\begin{array}{l}\cdot 69 \\
.98 \\
\cdot 34\end{array}$ & $\begin{array}{c}.94 \\
1.5 \\
.45\end{array}$ & $\begin{array}{l}1.2 \\
1.95 \\
\cdot 55\end{array}$ & $\begin{array}{r}1.85 \\
2.92 \\
.68\end{array}$ \\
\hline \multirow[t]{2}{*}{ Rostrum } & $\begin{array}{l}\mathbf{1} \\
\mathbf{2} \\
\mathbf{3} \\
\mathbf{4}\end{array}$ & $\begin{array}{l}\cdot 16 \\
\cdot 13 \\
\cdot 1 \\
\cdot 18\end{array}$ & $\begin{array}{l}\cdot 20 \\
\cdot 18 \\
\cdot 13 \\
\cdot 21\end{array}$ & $\begin{array}{l}\cdot 26 \\
\cdot 21 \\
\cdot 16 \\
\cdot 27\end{array}$ & $\begin{array}{l}\cdot 32 \\
.27 \\
.24 \\
\cdot 32\end{array}$ & $\begin{array}{l}.41 \\
.34 \\
.31 \\
.41\end{array}$ & $\begin{array}{l}.49 \\
.44 \\
.42 \\
.53\end{array}$ \\
\hline & Total length & .56 & $\cdot 70$ & $\cdot 87$ & $1 \cdot 1$ & $1 \cdot 39$ & $1 \cdot 84$ \\
\hline
\end{tabular}




\section{A Study of the Capsid Bugs found on Apple Trees}

length of the second antennal joint; the third joint is now longer than the fourth. A change in the shape of the thorax, owing to the increase in size of the wing pads which now reach the second abdominal segment. Other characters as in Instar III.

TABLe II. Plesiocoris RUgicollis.

\begin{tabular}{|c|c|c|c|c|}
\hline Stages & $\begin{array}{l}\text { Dates of hatchings } \\
\text { and of the various } \\
\text { instars }\end{array}$ & $\begin{array}{l}\text { Duration of } \\
\text { each instar }\end{array}$ & \multicolumn{2}{|c|}{$\begin{array}{l}\text { Records of hatchings and } \\
\text { moults obtained in the } \\
\text { laboratory }\end{array}$} \\
\hline Hatching & *May 5th-13th & - & - & - \\
\hline Instar I & $\begin{array}{l}\text { present from } \\
\text { May 5th-18th }\end{array}$ & 6 days & $\begin{array}{l}\text { Hatching } \\
\text { 5. v. } 17 \\
\text { 5. v. } 17 \\
\text { 5. v. } 17\end{array}$ & $\begin{array}{l}\text { lst moult } \\
\text { l1. v. } 17 \\
\text { l1. v. } 17 \\
\text { l1. v. } 17\end{array}$ \\
\hline Inatar II & $\begin{array}{l}\text { present from } \\
\text { May 11th-23rd }\end{array}$ & 4-5 days & $\begin{array}{l}\text { lst moult } \\
11 . \mathrm{v} .17 \\
\text { 11. v. } 17 \\
\text { 11. v. } 17 \\
\text { 12. v. } 17 \\
12 . \text { v. } 17\end{array}$ & $\begin{array}{l}\text { 2nd moult } \\
14 . \text { v. } 17 \\
15 . \text { v. } 17 \\
15 . \text { v. } 17 \\
16 . \text { v. } 17 \\
17 . \text { v. } 17\end{array}$ \\
\hline Instar III & $\begin{array}{l}\text { present from } \\
\text { May 15th-28th }\end{array}$ & 6 days & $\begin{array}{l}\text { 2nd moult } \\
\text { 14. v. } 17 \\
\text { 15. v. } 17\end{array}$ & $\begin{array}{l}\text { 3rd moult } \\
\text { 20. v. } 17 \\
21 . \text { v. } 17\end{array}$ \\
\hline Instar IV & $\begin{array}{l}\text { present from } \\
\text { May 20th-June 3rd }\end{array}$ & 5-7 dhys & $\begin{array}{l}\text { 3rd moult } \\
20 . \text { v. } 17 \\
20 . \text { v. } 17 \\
24 . \text { v. } 17 \\
24 \text {. } 17 \\
25 . \text { v. } 17 \\
\text { 31. v. } 17\end{array}$ & $\begin{array}{l}\text { 4th moult } \\
26 . \text { v. } 17 \\
25 . \text { v. } 17 \\
\text { 30. v. } 17 \\
\text { 31. v. } 17 \\
\text { 31. v. } 17 \\
6 . \text { vi. } 17\end{array}$ \\
\hline Instar V & $\begin{array}{c}\text { present from } \\
\text { May 25th-June 9th }\end{array}$ & 6-7 days & $\begin{array}{l}\text { 4th moult } \\
\text { 25. v. } 17 \\
\text { 28. v. } 17 \\
\text { 31. v. } 17\end{array}$ & $\begin{array}{l}\text { 5th moult } \\
\text { 1. vi. } 17 \\
\text { 4. vi. } 17 \\
\text { 6. vi. } 17\end{array}$ \\
\hline Adult & $\begin{array}{l}\text { present from } \\
\text { June 1st-July } 21 \text { st }\end{array}$ & about 6 weeks & - & 一 \\
\hline
\end{tabular}

- Fryer records these larvae as hatching before April 14th in 1913.

Instar V (Pl. X, fig. 9). Length 1.9-2.37 mm.

Characteristic peculiarities. Colour greener than in previous stages; second joint of antenna very long, nearly equal to the third and fourth together. Wing pads larger and reach the fourth abdominal segments. Yellow spot on abdominal segment III not noticeable. Other characters as in Instar IV. 
HABITS.

Plesiocoris rugicollis hatches out after the buds of the apple have opened and about 16-17 days before the flowers are in full bloom. Very soon the young larvae move to the opening buds and begin to feed on the tender opened or half-opened leaves which at this stage are not more that about an inch in length. On the opened leaves they usually feed from the upper surface more especially on each side of the mid-rib of the basal half of the lamina (see Pl. XI, fig. 12). They also feed on the upper surface of the rolled opening leaves and here they are partially concealed. Every leaf where they feed soen shows the characteristic brown spots. On being disturbed they run away very quickly and conceal themselves either in the curled leaves or the axils of the opened leaves. It is difficult to shake them off a branch at this stage, even when falling from one of the upper branches of a tree they hardly ever reach the ground but obtain a hold on one of the lower twigs either by means of their sharp claws or by extruding the posterior part of their alimentary canal which secretes a sticky fluid. The hairs on the leaves and stems of the apple seem to help them in regaining their hold as they are more easily shaken off the black currant. The later instars are more easily shaken off. At all stages they run very quickly but seem to be more active during the younger stages. They dodge like a squirrel by running to the opposite side of the stem and it is often difficult to catch them.

-They share with other insects the habit of cleaning their antennae by means of the hairs at the ends of the front tibiae after which they often rub their tibiae against each other. They moult in any situation, cast skins having been found on both surfaces of the leaves, on the petioles and on the stems. When ready to moult they become very sluggish and stop feeding. Moulting takes place by a longitudinal slit in the middorsal region of the thorax, this being preceded by a throbbing in the region of the callosities on the pronotum. The thorax and part of the head and abdomen come out first, followed by the legs and antennae and lastly by the rostrum. After moulting the bugs feed voraciously, making repeated stabs at the leaf at the rate of about fifty per hour.

The adults are easily shaken from the trees.

In walking through an infested orchard we have never seen them flying from one tree to another, but they can fly a fair distance when disturbed. When shaking them from a tree into a Bignell beating tray they often fly back again into the tree before reaching the tray and some of those which reach the tray fly back to the tree again. In the laboratory they 


\section{A Study of the Capsid Bugs found on Apple Trees}

usually flew towards the window in an almost horizontal direction, but some flew upwards and a few reached the ceiling.

\section{TIMe and Nature OF INJURY.}

In 1917 a very severe and prolonged winter was followed by a warm spring, the former retarding the opening of the buds and also the hatching of $\boldsymbol{P}$. rugicollis. Fryer records them as hatching before April 14th in 1913 and in 1916 a few newly hatched bugs were found on April 25th. In 1917 the first markings were seen on May 7th, but under warmer conditions in the laboratory a few hatched on May 5th. At this date the buds were opening rapidly, the diameter of well-opened buds being about one inch and a half, with the outer leaves about an inch long. The first attack started immediately after hatching and in a day or two a large number of buds showed the characteristic purple brown markings on their leaves. The number of attacked buds continued to increase rapidly on account of new larvae which kept hatching until May 13th and also because the earlier hatched larvae moved from one bud to another. It is probable that the hatching period, May 6th-May 13th, is shorter than the normal period owing to the warm condition obtaining at this period in 1917.

In some varieties and notably Lord Derby the leaves remained curled much longer than in other varieties and provided more shelter for the bugs. The time of full bloom of Early Victoria, Lord Grosvenor and Lady Hollendale was on May 23rd, i.e. about seventeen days after the bugs started to hatch and during this time the leaves were the source of food. In some varieties, e.g. Grenadier, the opened leaves were soon used up as a source of food and were very badly damaged, the bugs then began to feed on the closed part of the buds. This variety received a very bad check from the marking of the young leaves which did not expand to any extent (see Pl. XI, fig. 14 B).

When the fruit set the bugs were mostly in the fourth instar, some third and fifth instars also being present. These bugs began to mark the fruit on May 28th, very soon after setting. All the last three nymph stages and the adults damage the fruit. In cages in the laboratory they did not show any marked preference for the fruit but fed upon leaves and fruit alternately and seemed to be quite satisfied to feed at the place where they were put, except on old leaves.

They did not attack the fruit after it was over an inch in diameter but turned their attention to the young leaves and succulent part of the stem. When the adults appear the fruit is a fair size and not much 
damage is done to it by them, but the adults do most of the damage to the shoots. Where the young stem is attacked a brown fluid oozes out, the stem often cracks and is in some cases killed. When the terminal shoot is killed several of the buds below form shoots and a very thick tree results, especially when young trees are attacked. Most of the damage to the fruit is done by the Instars IV and V.

Wherever a $P$. rugicollis in any stage sucks a leaf a purplish brown spot appears after a short time, at first round but soon becoming irregular. The spot becomes irregular by spreading to the nearest small veins which form the boundaries of the spot and thus the shape of the marking is determined by the small veins between which the puncture is made. The area covered by the spot becomes thinner and sinks below the normal level of the surface of the leaf.

In older leaves the marking does not spread much but remains as a small spot. In all cases cork formation takes place round the seat of injury. When the puncture is very deep the whole of the mesophyll is affected, but in some punctures from the upper surface only the upper part of the mesophyll was injured and in some punctures from the lower surface only the lower part of the mesophyll turned brown. In many cases the epidermis over the brown spot appeared to be normal. Sections of injured leaves show that the mesophyll dies first and the epidermis afterwards. A badly damaged leaf sometimes remains shrivelled and eventually dies. Some badly damaged leaves do not die but remain crumpled and deformed, the dead tissue falling out and leaving a number of holes with a brown margin. In several trees of the variety Grenadier the leaves were so badly punctured that very little growth was made until late in the season. In a mild attack the leaves may grow fairly well whilst showing the small brown marks. Occasionally a vein is punctured and a brown spot results.

The injury to the fruit varies with the variety. In the slower growing varieties like Lady Hollendale and Worcester Pearmain the damage is enormous and badly marked apples do not grow even to one-quarter of their normal size and often fall off. In the quicker growing varieties like Bramley's Seedling and Early Victoria the fruit grows out of the injury more, and although corky markings and peculiar shaped apples may result, the reduction of the crop is not nearly so marked.

When a bug punctures the young fruit a small drop of fluid exudes from each puncture. These drops eventually dry up and leave a brown mark in the fruit (see Pl. XI, fig. 13). The tissue around the seat of injury forms cork and is therefore prevented from making normal growth, 


\section{A Study of the Capsid Bugs found on Apple Trees}

dimpled or malformed fruit resulting. In a young apple the injury extends several cells below the cuticle, but in an old apple there is no discoloration of the flesh under the cork layer.

Punctured apples in their late stages show a russetting due to the brown cork scars and in some varieties they crack badly. Practically all the damage to the fruit is done before it reaches an inch in diameter, probably because later on it is too hard to be easily punctured. In one or two cases adults were found dead with their probosces inserted into the tissue of medium-sized fruits. Cork formation follows the punctures in leaves, fruit and young shoots.

\section{The CaUSE OF INJURY.}

It has been suggested $(1,14)$ that the injury done by a capsid is due to the mechanical laceration of the tissues by the barbed stylets of its rostrum. There is no doubt that the ends of the stylets are barbed and that the bug does puncture the plant repeatedly, but how far this laceration is responsible for the brown spots or any other external sign of damage is difficult to say. A number of different capsids were found feeding on the same trees but only in the case of $P$. rugicollis was any visible damage done.

The stylets of all these capsids are very similar and it seems to us that the cause of the damage is chemical rather than mechanical, the salivary injection from $P$. rugicollis being lethal to the tissue of apple trees whilst that of the other species is not. This is supported by the fact that it is the mesophyll and not the epidermis which shows the first signs of injury, and dead mesophyll may be present under a healthy epidermis, and again the damaged area may spread for some time after laceration has taken place.

This brings us to an interesting biological problem. The injury done to a plant may be mechanical or physiological, and although the final result to the plant may be the same it seems necessary to distinguish these two kinds. The term "mechanical injury" might be used to include the wounding of plants by eating away parts of them or by sucking the juices. The term "physiological injury" might mean the injection of some material into the plant which kills the tissue or brings about abnormal growth. The same species might be responsible for both mechanical and physiological damage.

It seems probable that in the case of Plesiocorus rugicollis the mechanical injury is of little consequence. Psallus ambiguus and Orthotylus marginalis were sometimes as numerous as that species and 
yet the injury caused by their sucking the juices was of no importance. An insect that causes mechanical injury would probably do so to all plants that it feeds on but it is possible that the injection of an insect that causes physiological injury might affect different plants in different ways and even be harmless to some plants and also much less harmful to some varieties of plants of the same species.

It is interesting to find that certain pests are specific in their attacks whereas others infect a large number of plants. Lygus pratensis is known to attack fifty different species of plants (7). Plesiocoris rugicollis was formerly known to attack Salix and Alnus but it now attacks apple, black and red currants and under experimental conditions has been made to attack plums. This interesting change in the diet of a species is possibly comparable with mutations in the morphological characters and may be due to some physiological mutation in the organism. It is possible that $P$. rugicollis may in the future extend its host plants and so become a still more serious pest.

The change in its diet is difficult to explain but it may be due to a very simple cause. Larvae cannot fly and when just hatched do not appear capable of travelling far, and their only chance of living seems to be to suck the juice of the plant on which the eggs are laid. They get used t", this diet and so do not change it readily. Suppose a fertilised femals to be blown on to a new host and not capable of reaching her former host, she may lay eggs there and if she can live on the juices of this host the larvae which hatch from these eggs will probably be able to live on the tissues of the host on which their mother could live, and in any case are unable to reach the original host of their mother. Actual experimental evidence is wanting, but we know that nymphs can be made to change their hosts, e.g. apple to plum, and black currant to apple, and it would be interesting to see if $P$. rugicollis could be made to lay eggs on a species other than that on which it was reared.

The facts that apples and willows are found interlacing and only the willows attacked by $P$. rugicollis and also apples and black currants interlaced with only the latter attacked show that it normally lays its eggs on the host on which it has fed and does not readily change its host when that host is capable of providing it with food.

In the Wisbech district $P$. rugicollis lives on willows, apples, black currants and red currants, whereas in certain districts near Cambridge it does not live on apples but does on the other three. Larvae from black currants near Cambridge were sleeved on apple trees and although they did not feed readily at first eventually became used to their new host 


\section{A Study of the Capsid Bugs found on Apple Trees}

and completed their development. They begin to feed more readily if transferred in the early larval stages than in the later stages. Larvae from apples also reached the adult stage when sleeved on black currants. In an orchard at Great Eversden where for several years black and red currants have been attacked, this year the rows of apples near them, Worcester Pearmain, are also attacked.

The black currant leaves are much thinner than apple leaves and consequently the brown marks caused by the bugs soon fall out and leave holes with a brown margin.

Larvae of $\boldsymbol{P}$. rugicollis when sleeved on plum caused a few markings but did not live long. The injury was similar in appearance to that of black currant.

Taylor(23) and Collinge(5) attribute the dimples in apple fruit to the eggs of Lygus pratensis which are also laid in the stalk of the fruit which may consequently fall off. This is not the case with $P$. rugicollis.

\section{Control.}

It has been shown by experiments $(12,12 a$ and some carried out in 1917 by one of us) that $P$. rugicollis can be kept in check by spraying with "soft soap and nicotine." The amount of soft soap necessarily varies with the hardness of the water, 1.0 per cent. or even less is sufficient for soft water but it may be better to use more than this for hard water. 0.05 per cent. of nicotine (98-99 per cent.) is sufficient. This wash kills the bugs very quickly in all stages except the egg stage.

In order to have its maximum effect the wash should be applied just after all the bugs have hatched and spraying may continue for some time after the fruit has become marked. It is necessary to spray with a powerful jet and for this purpose a high pressure pump and a fairly coarse nozzle should be used. The trees should be thoroughly drenched and sprayed in a downward direction, keeping the nozzle fairly close to the opening leaves.

As the eggs are laid in the young shoots, trees from an infested nursery should not be planted in non-infested areas.

\section{SUMMARY OF THE LIFE-HISTORY OF A CAPSID.}

Although these bugs do not undergo a sudden ohange at any moult, yet each stage possesses characteristic festures. The following is a brief summary of these peculiarities founded on the study of the capsids dealt with in this paper and others that have come under our notice and will be applicable to a large number of species. 
Instar I. Smoky shade on dorsal surface of head, thorax and first abdominal segment, interrupted in the region of the thorax by a middorsal pale line which continues on the head and bifurcates at the level of the eyes (see Pl. IX, fig. 5).

Longitudinal groove present on the head.

Terminal joint of antenna the longest.

Instar II ${ }^{1}$ (Fig. 6). No smoky shade.

Terminal joint of antenna slightly longer than the second.

No wing pads.

Instar III (Pl. X, fig. 7). Small but distinct wing pads.

Second joint of antenna the longest.

Instar IV (Fig. 8). Wing pads reach second abdominal segment.

Second antennal joint relatively longer.

Instar $V$ (Fig. 9). Wing pads reach fourth abdominal segment.

Second antennal joint still longer.

All these instars have 2-jointed tarsi.

6. ORTHOTYLISS MARGINALIS REUT. (NASSATUS FALL. ET AUCT.).

This species hatches about a fortnight later than $P$. rugicollis and $P$ sallus ambiguus. The adult resembles $P$. rugicollis in its green colour but can be readily distinguished from it by the absence of a collar and the two callosities on the pronotum; it is moreover covered with fine white hairs. The eyes nearly touch the pronotum.

The antennae are slender, medium sized, with the basal joint somewhat pale in both sexes, and the terminal joint with no pink colour.

A very distinct orange spot is present between the last two pairs of coxae.

Male with asymmetrical genital forceps, that of the left side having two conspicuous prongs.

It is mentioned by Theobald (24, 28) and Schöyen (21) as a pest of apples but we find no evidence for this. We have found it in considerable numbers in uninjured orchards.

The egg of Orthotylus marginals is smaller than that of $P$. rugicollis, being only $0.95 \mathrm{~mm}$. in length. It resembles the rubber part of a fountain pen filler with the open end flattened laterally.

It differs from the egg of $P$. rugicollis in that the transverse section of the cap is much longer than it is wide and the cap itself is convex.

It is slightly curved in the region of the neck (cf.Pl.IX, figs. $4 \mathrm{~A}$ and B).

1 Crosby and Leonard's (7) third and fourth stage are alike and what they describe as second stage is really the third. 


\section{A Study of the Capsid Bugs found on Apple Trees}

We dissected out eggs from a female but did not find any eggs in the stems. Females were put on shoots in cages but we were unable to find any eggs in these shoots.

The eggs are undoubtedly laid in the stems because the larvae hatch out on the twigs.

Instar 1 . Length $1 \cdot 17-1 \cdot 26 \mathrm{~mm}$.

In shape very similar to Instar I of $P$. rugicollis but smaller and distinguishable by the bright orange-yellow dorsal abdominal gland, which

Table 1 II.

ORTHOTYLCS MAROINALIS (MEASUREMENTS IN MILLIMETRE).

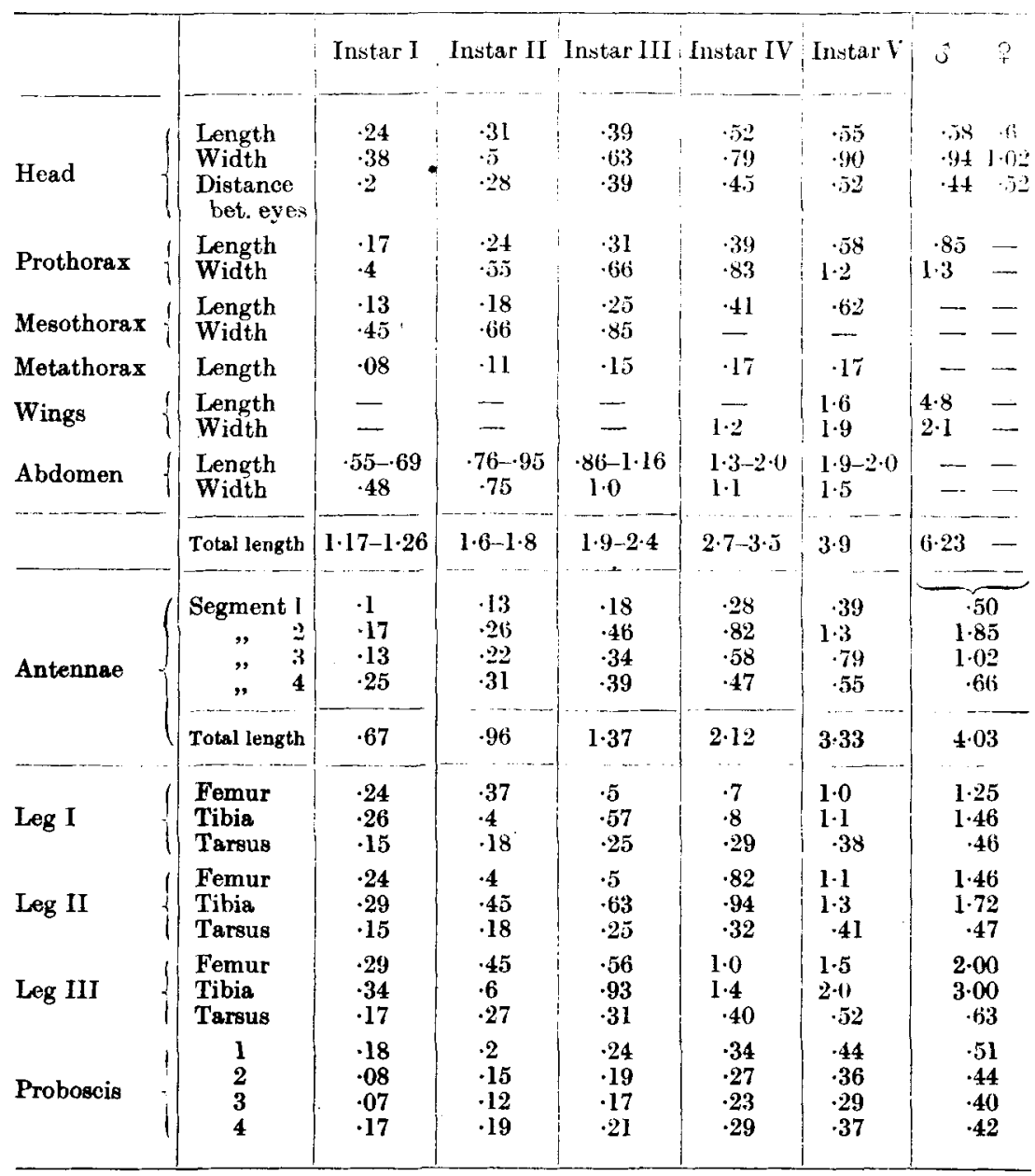


is easily seen by the naked eye through the chitin. Lips of this gland very light brown and not so noticeable as in $P$. rugicollis.

Yellowish green in colour, eyes dark red with a white margin round them. Thorax and abdomen covered with long white hairs. Antennae light orange with a dusky chitin; terminal joint of same colour, not pink as in $P$. rugicollis. Other characters typical of first Instars (see p. 199).

Instar II. Length 1.6-1.8 $\mathrm{mm}$.

Peculiarities typical of Instar II (see p. 199), otherwise as Instar I except for a slight bluish tinge, especially underneath.

Instar III. Length 1.9-2.4 $\mathrm{mm}$.

Peculiarities typical of Instar III (see p. 199), otherwise as previous instar.

Instar IV. Length $2 \cdot 7-3.5 \mathrm{~mm}$.

Peculiarities typical of Instar IV (see p. 199), otherwise as previous instar.

Instur $V$. Length $3.9 \mathrm{~mm}$.

Peculiarities of Instar V (see p. 199), otherwise as previous instar.

The last three instars have a definite bluish tinge.

\section{PSALLUS AMBIGUUS (FALL.) (OBSCURUS D. AND S.).}

This species hatches out about the same time as $P$. rugicollis. A large number were found in the orchards at West Walton. They are very shy during the first two stages and lie concealed in the axils of the leaves and it is very difficult to see them and still more difficult to dislodge them by beating or shaking. They were found equally frequently in damaged and undamaged buds, and their behaviour in cages and in sleeves definitely proved that these were not associated with the injury done to the leaves and fruit. They were present at the University Farm, Cambridge, and at Histon where there was no trace of damage. We found them too frequently on apple shoots brought for our cages, but never found any damage on these and consequently we regard this species as harmless. One fact is very significant and requires elucidation. As pointed out above the larvae of Psallus ambiguus lived for weeks on absolutely dried shoots with no leaves and several of them reached the fourth instar stage. This suggests that their source of food may be something other than plant juices. There were present on these twigs, eggs and nymphs of the apple sucker (Psylla mali) and also eggs and young of the red spider (Tetranychus sp.). There is no doubt that they do suck plant juices as we have seen them doing so, but we have also

Ann. Biol. IV 


\section{A Study of the Capsid Bugs found on Apple Trees}

seen them sucking the dead bodies of other capsids and it seems probable that they may be carnivorous and consequently beneficial.

The duration of each instar is very much the same as in the case of $P$. rugicollis.

Instar I. Length 1.0-1.4 mm.

Yellow, eyes crimson with a white edge round them.

Thorax and abdomen covered with long white hairs.

Table IV. Psallus ambiguUs (measurements in millimetres).

\begin{tabular}{|c|c|c|c|c|c|c|c|}
\hline & & Instar I & Instar II & Instar III & Instar IV & Instar V & Adult \\
\hline Head & $\begin{array}{l}\text { Length } \\
\text { Width } \\
\text { Distance } \\
\text { between } \\
\text { the eyes }\end{array}$ & $\begin{array}{l}\cdot 24 \\
.37 \\
.28\end{array}$ & $\begin{array}{l}\cdot 31 \\
\cdot 48 \\
\cdot 31\end{array}$ & $\begin{array}{l}.35 \\
.57 \\
.34\end{array}$ & $\begin{array}{l}.4 \\
.69 \\
.4\end{array}$ & $\begin{array}{l}.43 \\
.8 \\
.45\end{array}$ & $\begin{array}{l}.43 \\
.86 \\
.45\end{array}$ \\
\hline Prothorax & $\begin{array}{l}\text { Length } \\
\text { Width }\end{array}$ & $\begin{array}{l}\cdot 17 \\
\cdot 37\end{array}$ & $\begin{array}{l}.26 \\
.51\end{array}$ & $\begin{array}{l}.29 \\
.59\end{array}$ & $\begin{array}{l}.43 \\
.76\end{array}$ & $\begin{array}{l}.48 \\
1.0\end{array}$ & $\begin{array}{l}.72 \\
1 \cdot 6\end{array}$ \\
\hline Mesothorax & $\begin{array}{l}\text { Length } \\
\text { Width }\end{array}$ & $\begin{array}{l}.12 \\
.45\end{array}$ & $\begin{array}{l}\cdot 17 \\
\cdot 6\end{array}$ & $\begin{array}{l}.25 \\
.68\end{array}$ & $\stackrel{37}{-}$ & $\stackrel{57}{-}$ & .81 \\
\hline Metathorax & $\begin{array}{l}\text { Length } \\
\text { Width }\end{array}$ & $\begin{array}{l}\cdot 11 \\
.51\end{array}$ & $\begin{array}{r}.12 \\
.67\end{array}$ & $\begin{array}{l}.13 \\
.75\end{array}$ & .15 & 15 & - \\
\hline Wings & $\begin{array}{l}\text { Length } \\
\text { Width of body } \\
\text { in the region } \\
\text { of wings }\end{array}$ & - & - & - & $\begin{array}{l}\cdot 77 \\
1 \cdot 1\end{array}$ & $\begin{array}{l}1 \cdot 4 \\
1.5\end{array}$ & $\begin{array}{l}3 \cdot 41 \\
1 \cdot 8\end{array}$ \\
\hline \multirow[t]{2}{*}{ Abdomen } & $\begin{array}{l}\text { Length } \\
\text { Width }\end{array}$ & $\begin{array}{c}\cdot 48-62 \\
\cdot 56\end{array}$ & $\begin{array}{c}\cdot 8-88 \\
\cdot 68\end{array}$ & $\begin{array}{l}.94-1 \cdot 1 \\
.85\end{array}$ & $\begin{array}{l}1 \cdot 3-1 \cdot 6 \\
1 \cdot 2\end{array}$ & $\begin{array}{l}1.7-1.9 \\
1.4\end{array}$ & - \\
\hline & Total length & $1 \cdot 0-1 \cdot 4$ & $1 \cdot 6-1 \cdot 8$ & $2 \cdot 1-2 \cdot 3$ & $2 \cdot 6-3 \cdot I$ & $3 \cdot 28-3 \cdot 6$ & $4 \cdot 5$ \\
\hline \multirow[t]{2}{*}{ Antennae } & $\begin{array}{l}1 \\
2 \\
3 \\
4\end{array}$ & $\begin{array}{l}.07 \\
.15 \\
.13 \\
.25\end{array}$ & $\begin{array}{l}\cdot 14 \\
\cdot 28 \\
.22 \\
\cdot 31\end{array}$ & $\begin{array}{l}\cdot 16 \\
\cdot 4 \\
\cdot 31 \\
.28\end{array}$ & $\begin{array}{l}.2 \\
.6 \\
.4 \\
.32\end{array}$ & $\begin{array}{l}.28 \\
.85 \\
.52 \\
.36\end{array}$ & $\begin{array}{c}.36 \\
1 \cdot 17 \\
\cdot 58 \\
.4\end{array}$ \\
\hline & Total length & .60 & .95 & $1 \cdot 15$ & 1.52 & $2 \cdot 11$ & $2 \cdot 51$ \\
\hline Leg I & $\begin{array}{l}\text { Femur } \\
\text { Tibia } \\
\text { Tarsus }\end{array}$ & $\begin{array}{l}\cdot 27 \\
\cdot 3 \\
\cdot 16\end{array}$ & $\begin{array}{l}\cdot 34 \\
\cdot 36 \\
\cdot 19\end{array}$ & $\begin{array}{l}-41 \\
\cdot 5 \\
\cdot 22\end{array}$ & $\begin{array}{l}.54 \\
.54 \\
.27\end{array}$ & $\begin{array}{l}\cdot 7 \\
.81 \\
.3\end{array}$ & $\begin{array}{c}.9 \\
1 \cdot 1 \\
\cdot 36\end{array}$ \\
\hline Leg II & $\begin{array}{l}\text { Femur } \\
\text { Tibia } \\
\text { Tarsus }\end{array}$ & $\begin{array}{l}.28 \\
.32 \\
.16\end{array}$ & $\begin{array}{l}.36 \\
.43 \\
.19\end{array}$ & $\begin{array}{l}.51 \\
.58 \\
.23\end{array}$ & $\begin{array}{l}.63 \\
.72 \\
.28\end{array}$ & $\begin{array}{c}\cdot 9 \\
1 \cdot \mathrm{I} \\
\cdot 35\end{array}$ & $\begin{array}{l}1 \cdot 0 \\
1 \cdot 4 \\
.38\end{array}$ \\
\hline Leg III & $\begin{array}{l}\text { Femur } \\
\text { Tibia } \\
\text { Tarsus }\end{array}$ & $\begin{array}{r}\cdot 39 \\
\cdot 43 \\
\cdot .19\end{array}$ & $\begin{array}{l}\cdot 41 \\
.5 \\
.23\end{array}$ & $\begin{array}{l}.63 \\
.79 \\
.28\end{array}$ & $\begin{array}{c}\cdot 8 \\
1 \cdot 1 \\
\cdot 36\end{array}$ & $\begin{array}{l}I \cdot 1 \\
1 \cdot 62 \\
\cdot 49\end{array}$ & $\begin{array}{l}1 \cdot 4 \\
2 \cdot 1 \\
\cdot 58\end{array}$ \\
\hline Proboscis & $\begin{array}{l}1 \\
2 \\
3 \\
4\end{array}$ & $\begin{array}{l}\cdot 16 \\
\cdot 12 \\
.09 \\
\cdot 18\end{array}$ & $\begin{array}{l}.20 \\
.15 \\
.12 \\
.21\end{array}$ & $\begin{array}{l}.27 \\
\cdot 19 \\
\cdot 18 \\
.27\end{array}$ & $\begin{array}{l}\cdot 3 \\
\cdot 27 \\
\cdot 23 \\
\cdot 3\end{array}$ & $\begin{array}{l}.41 \\
.38 \\
.30 \\
.40\end{array}$ & $\begin{array}{l}\cdot 45 \\
\cdot 41 \\
\cdot 36 \\
\cdot 45\end{array}$ \\
\hline
\end{tabular}


Yellow dorsal abdominal gland with faintly marked lips.

Antennae pale orange with a dusky shade in the chitin; terminal joint of same colour, not pink as in $P$. rugicollis.

Other characters typical of first Instars.

Instar II. Length 1.6-1.8 mm.

Peculiarities typical of Instar II (see p. 199), otherwise as Instar I.

Instar III. Length $2 \cdot 1-2 \cdot 3 \mathrm{~mm}$.

Antennae darker, basal joint darkest.

Head yellow; thorax and abdomen greyish yellow with a green tinge. Eyes dark red with a white margin.

Peculiarities typical of Instar III (see p. 199), otherwise as Instar II. Instar IV. Length $2 \cdot 6-3 \cdot 1 \mathrm{~mm}$.

Peculiarities typical of Instar IV (see p. 199), otherwise as Instar III. Instar $V$. Length 3.28-3.6 mm.

Peculiarities typical of Instar V (see p. 199), otherwise as Instar IV. Adult. - Length $4.5 \mathrm{~mm}$.

Oval: o dark brown; $q$ varies from grey to dark brown, cuneus always reddish.

Body covered with long pale hairs which easily rub off.

No collar on pronotum.

\section{ATRACTOTOMUS MALI (MEY.).}

This species has been accused of doing great damage to the apple in Suffolk and Hereford (26) but in all our experiments we have found it to be quite harmless. It was not found in any great numbers either at Wisbech or at Cambridge, but the trees on which they were found in fair numbers, two or three on one shoot, showed no marks or signs of injury. While one $\boldsymbol{P}$. rugicollis larva would cover two or three fair sized leaves with brown spots in one night, two even three or four nymphs kept in cages for days on the same shoot did not mark them. We regard this species as quite harmless.

Instar V (Pl. X, fig. 11). Small, broad, ovate nymph, with deep dark red colour, very dark on the anterior part of pronotum, wing pads and two basal antennal joints.

Antennae medium sized with two basal joints very thick and dark red, thickly covered with black hairs.

The two terminal joints cream coloured with a faint tinge of orange in the terminal joint.

Femora red, tibiae upper half red, lower half and tarsi pale.

Proboscis reaches the second coxae.

Peculiarities typical of Instar V. 


\section{A Study of the Capsid Bugs found on Apple Trees}

\section{THE ENEMIES OF CAPSIDS.}

We gave very little attention to this side of the subject but we never found any insect attacking capsids. We found a cimicid Anthocoris sylvestris sucking the dead bodies of capsids at various stages and we also saw several species of capsid sucking the dead body of the same or different species. It is possible that Anthocoris sylvestris and also some species of capsids, e.g. Psallus ambiguus, are capable of killing live capsids, but we have never observed them doing so.

The young capsids are so active except at moulting that they would probably escape from such enemies as those which attack aphis. We found dead capsids on the trees and on healthy shoots in cages but we were unable to assign a causal organism.

\section{THE FOOD OF APPLE-DWELLING CAPSLDS.}

Both the nymphs and adults of Plesiocoris rugicollis live mainly on the juices of the leaves, stem and fruit of various species of plants, but they have been seen sucking dead individuals of the same or another species. Where they suck another bug a blackish mark is formed. This is also true of Psallus ambiguus, Orthotylus marginalis, Atractotomus mali and larvae of Phytocoris ulmi. Atractotomus mali has been recorded as attacking caterpillars of Hyponomeuta $(13,20)$, and in one case we found a large number of adults near a nest of these caterpillars. Such large numbers were never found together in any other place.

Psallus ambiguus feeds on plant juices but it can live for several weeks on dried twigs on which nymphs and adults of Psylla mali and young forms of Tetranychus sp. w.ere present. No definite observations were made as to its carnivorous nature, but Rymer Roberts writes that "a nymph of Psallus ambiguus fed on Aphis avenae and also on two syrphid eggs."

\section{REFERENCES.}

1. Awati, P. R. Proc. Zool. Soc. Lond. 1914, p. 685.

2. Brittaln, W. H. The Canadian Horticulture. Dec. 1915

3. — Rev. App. Ento. Dec. 1916.

4. Cafsar. Ent. Soc. Ontario, 1912, p. 102.

5. Colutnge. Journal ECo. Biol. vol. vir. p. 64.

6. Crosby. Cornell Uni. Bull. No. 291, 1911.

7. Crosby and Leonard. Cornell Uni. Bull. No. 364, 1911. Give a long list of literature on Capsidae.

8. Dodgras and ScotT. A Catalogie of British Hemiptera, 1876.

9. Fat.tkr, C. F. Monographia cimicum sveciae, 1818, p. 76 .

10. Fieb Fr, F. X. Die Europäischen Hemiptera Halbflügler, 1861, p. 272.

11. Fry ER, J. C. F. Preliminary notes on the damage of apples by Capsid Bugs. The Annals of App. Biol. vol. I. no. 2, 1914.

12. FrYer, J. C. F. Journal Board of Agriculture, Jan. 1916. 
THE ANNALS OF APPLIED BIOLOGY. VOL. IV, NO. 4

PLATE IX

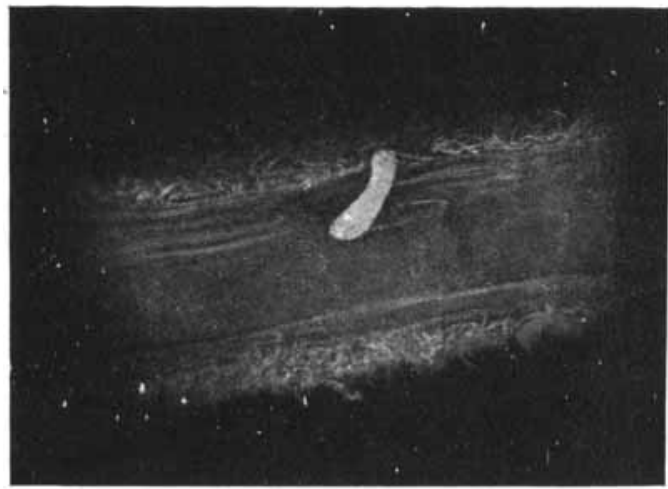

1

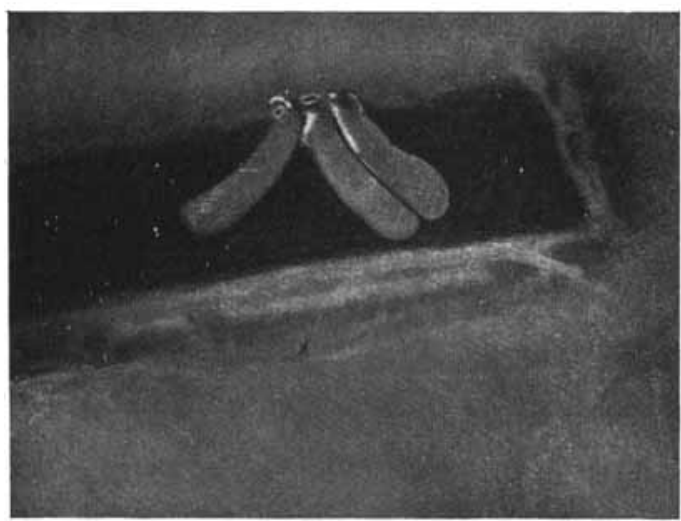

3

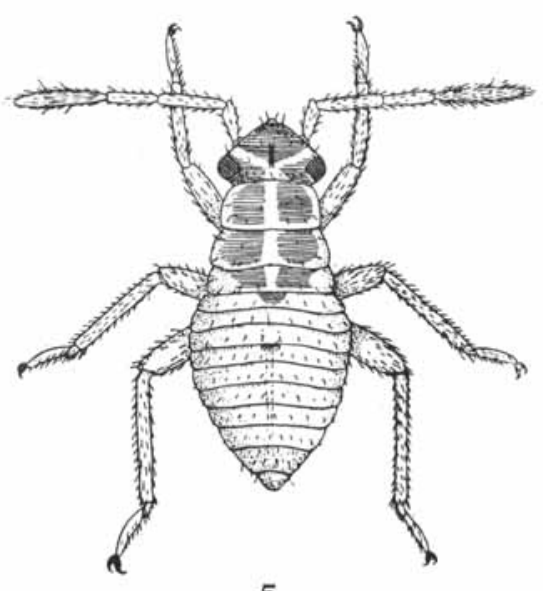

5

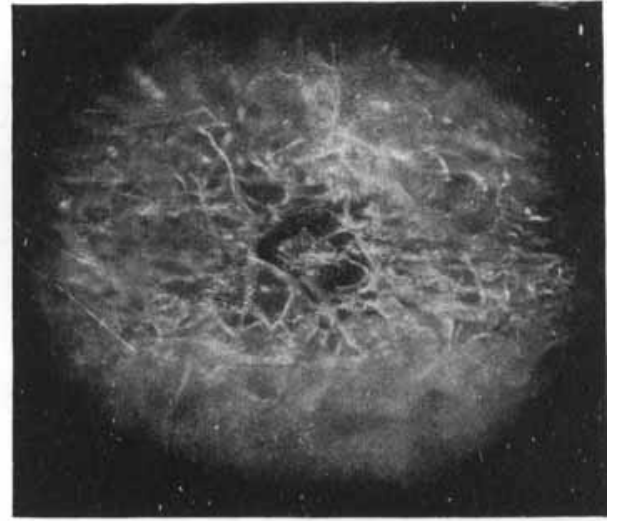

2
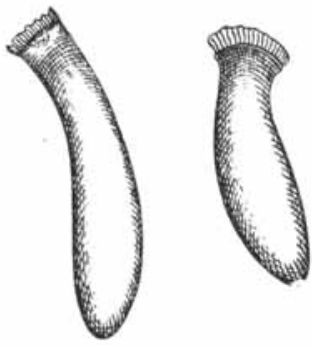

A

B

4

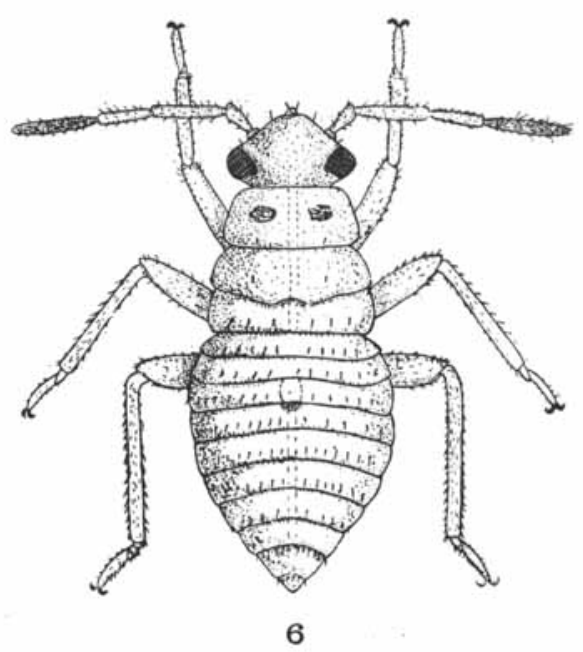




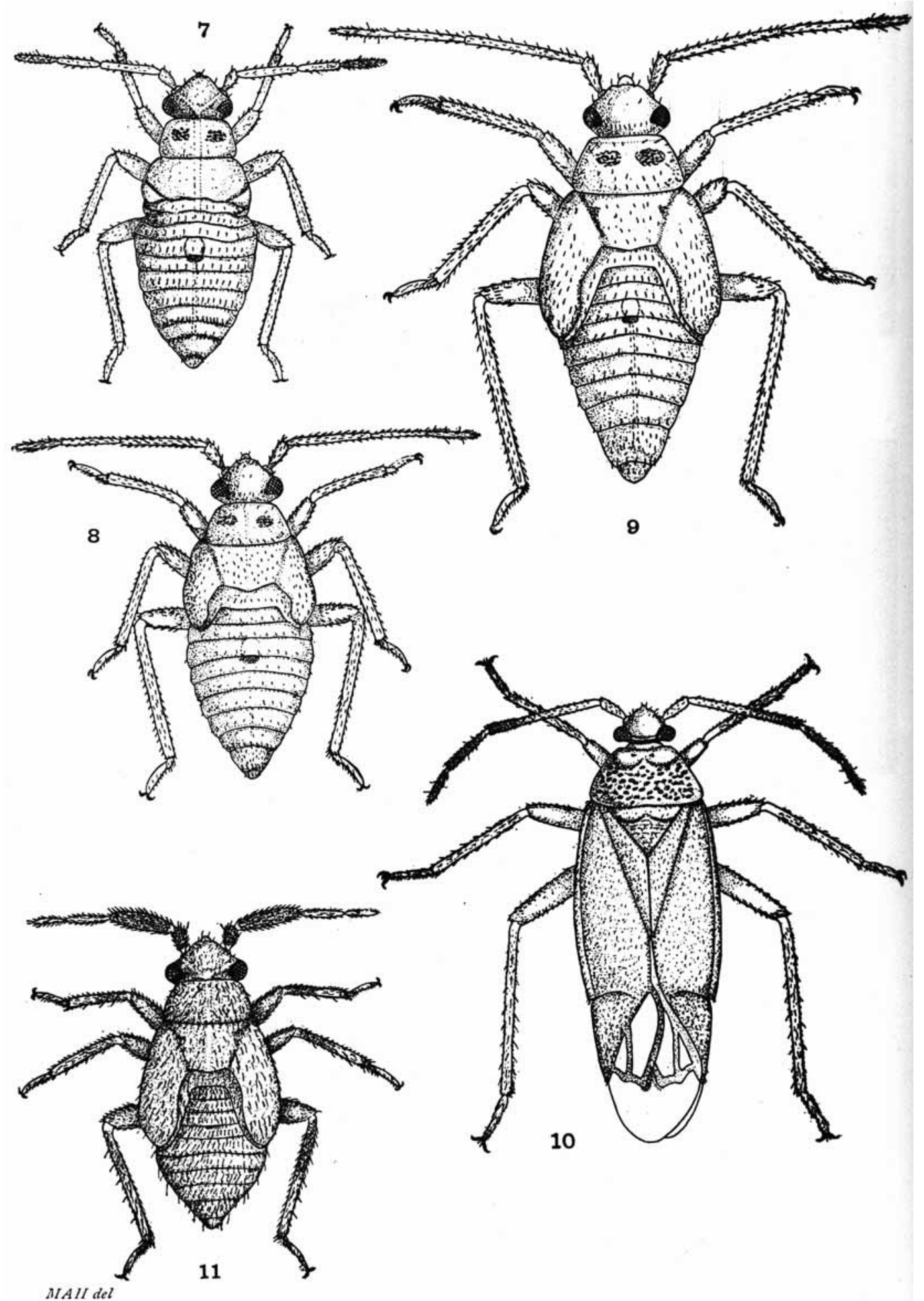


THE ANNALS OF APPLIED BIOLOGY. VOL. IV, NO. 4
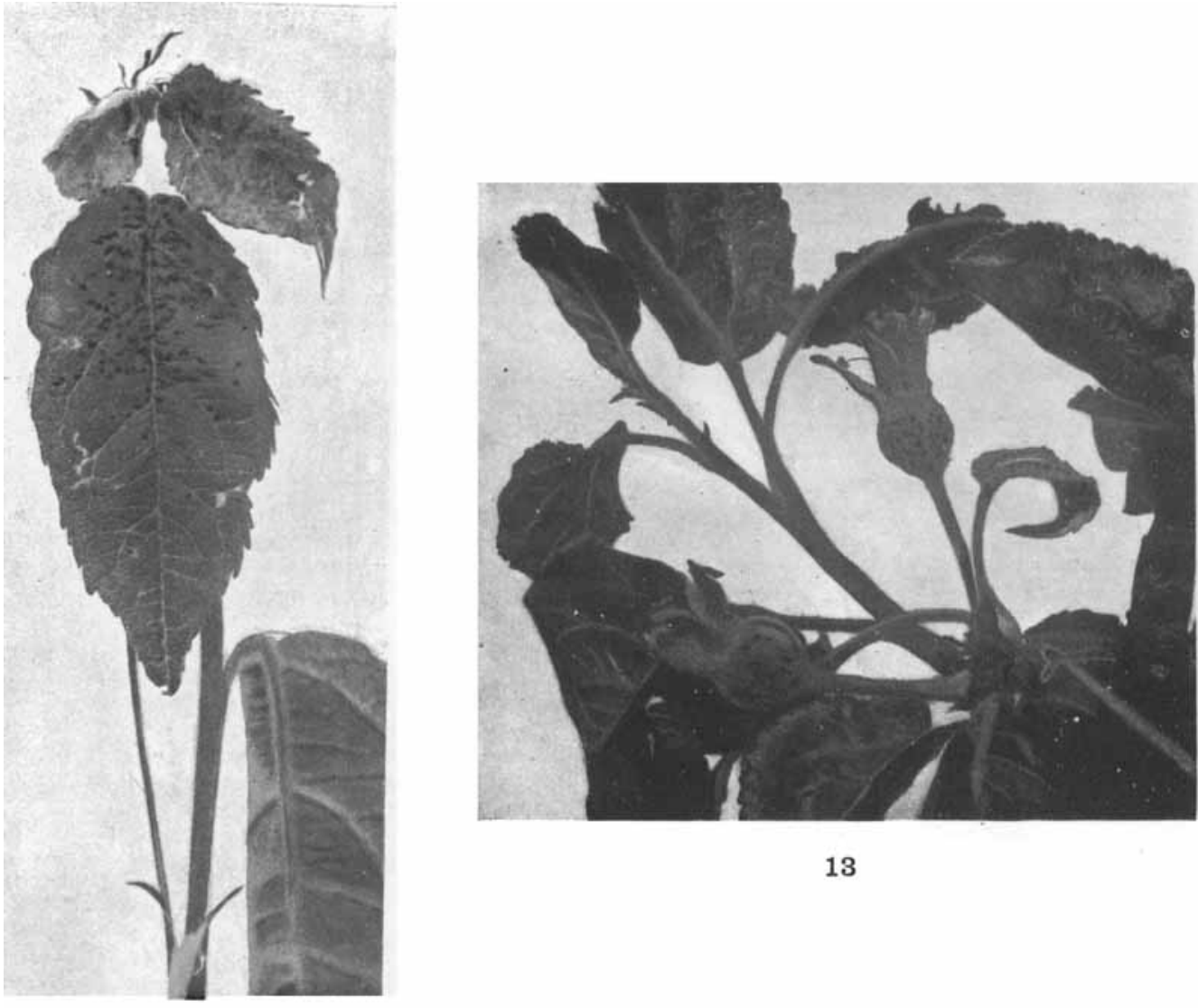

13

12

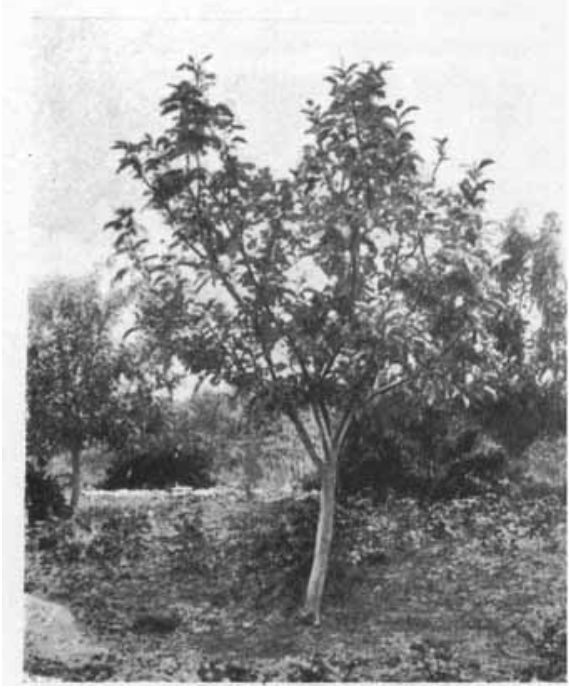

$14 \mathrm{~A}$

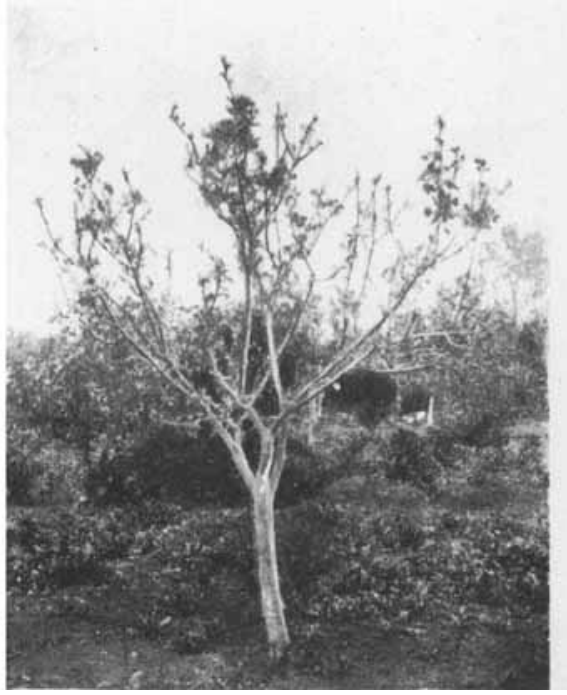

$14 \mathrm{~B}$ 

12 a. Fry err, J. C. F. and Petherbridge, F. R. Journal of the Board of Agriculture, April, 1917.

13. GIARD, A. Sur un Hemiptère Atractotomus mali (Mey.) parasite dechenilles d'Hyponomeuta malinellis. Bull. de la Soc. Ent. de France, 1900.

14. Horne, A. S. and LEFroY, H. M. Effects produced by sucking Insects and Red Spiders on Potato foliage. The Annals of App. Bioi. vol. x.

15. KNIGHT, H. H. Observation on the oviposition of certain capsids. Jour. Geo. Ent. 1915.

16. Leovard. Immature stages of Plagiognathus politus Uhler and Compylomma verbosci Henick-Schaeffer. Jour. New York Ent. Soc. vol. xxIII.

17. Oschanin, B. Verzeichnis Palaearktischen Hemiptera. Bd. I. Heteroptera, p. $733,1909$.

18. Parrot and Hodgriss. New York Agr. Exp. Sta. Bull. No. 368, 1913.

19. REUTER. Hemiptera Gymnocerata Europae. XXI. No. 2. Acta Societatis Scientiarum Finnicae.

20. — Food of Capsids. Ent. Month. Mag. vol. XIv. pp. 121-127, 1903.

21. SCHÖYEN. Beretning on Skadeinseketer og plantisygdommer $i$ land og havebrukt, 1914.

22. SoraUder, P. Handbuch der Pflanzenkrankheiten, Bd. III. p. 630, 1913.

23. TAYLOR, E. P. Jour. Geo. Ent. vol. I. p. 371.

24. TheOBALD, F. V. Report on Economic Zoology, 1910, p. 37.

25. - Report on Economic Zoology, 1912, pp. 23-25.

26. - Journal of the Board of Agriculture, 1913, p. 112.

27. — Report on Economic. Zoology, 1913, pp. 27-33.

28. - Report on Economic Zoology, 1914.

29. Weaster and Stoner. Life history of Calocoris rapidus. Jour. New York Ent. S'c. vol. XXIr. pp. 229-234, 1914.

\section{EXPLANATION OF PLATES.}

PLATE IX.

Fig. 1. Egg of Plesiocoris rugicollis in situ.

Fig. 2. Surface view of the cap of an egg of Plesiocoris mugicollis in situ.

Fig. 3. Eggs of Plesiocoris rugicollis in situ.

Fig. 4. A. Egg of Plesiocoris rugicollis.

B. Egg of Orthotylus marginalis.

Fig. 5. Plesiocoris rugicollis, Instar I.

Fig. 6. , " " II.

PLATE $X$.

Fig. 7. Plesiocoris rugicollis, Iristar III.

Fig. 8. " " " IV.

Fig. $9 . \quad$ " $\quad "$ "

Fig. 10. , , Adult.

Fig. 11. Atractotomus,mali, Instar V.

PLATE XI.

Fig. 12. Apple leaves marked by Plesiocoris rugicollis.

Fig. 13. Young apples marked by Plesiocoris rugicollis.

Fig. 14. Two apple trees (variety Grenadier).

A. Sprayed and showing normal growth.

B. Unsprayed and showing a severe check to the growth of the lesves due to Plesiocoris rugicollis. 